\title{
MOLECULAR CHARACTERIZATION AND IDENTIFICATION OF THREE STORED GRAIN PESTS BASED ON MITOCHONDRIAL CYTOCHROME C OXIDASE SUBUNIT I (COI) GENE SEQUENCES
}

Abu Faiz Md. Aslam*, Sharmin Sultana, Faria Farhana Rain, Susmita Sarker, Sumita Rani Das, Ayesha Siddika and Abdul Jabber Howlader

Department of Zoology, Jahangirnagar University, Savar, Dhaka-1342, Bangladesh

\begin{abstract}
Stored grain pests are discovered in food as immature stages, which further complicates the identification process. A DNA barcode dataset of some important pests that can be used for easy and confirm identification in stages of life is constructed. COI genes of three stored grain insect pests i.e, Sitophilus oryzae, Callosobruchus chinensis and Oryzaephilus surinamensis were sequenced. The sequenced genes were submitted to NCBI GenBank and obtained accession numbers MG967331.1, MG967332.1, MG967333.1 and MK041216.1. BLAST analysis showed 99 to $100 \%$ homology with existing GenBank sequences. The nucleotide composition analysis revealed that the value of $\mathrm{A}+\mathrm{T}(64.8 \%)$ is greater than $\mathrm{G}+\mathrm{C}(35.2 \%)$. Genetic distance among four sequences of three store pests were ranged from 0.00293-0.32807. Phylogenetic analysis showed that these three species are originated from different clades. Haplotype analysis of mitochondrial COI gene of the stored grain insect pests showed high genetic diversity among them. C. chinensis, O. surinamensis and S. oryzae were separated from their common ancestor by 80,73 and 64 mutational steps. These information may be helpful for attempting any successful control measures against the pest species. In conclusion, present author established the first DNA barcode dataset of three store grain pests and confirmed its efficiency for identifying these pests.
\end{abstract}

Key words: Molecular characterization, DNA barcode, stored grain pest,

Cytochrome oxidase, phylogeny

\section{INTRODUCTION}

Paddy, wheat, maize, varieties of pulses, pea, lentil, joar, bajra, kaon, oil seeds, potatoes, spices, tobacco and many other agricultural products are stored both as seed and food in many countries of the world (Bhuiyah et al. 1990). It has been estimated that between one quarter and one third of the world grain crop is lost each year during storage mainly due to insect attack (Hill 1990, Oerke et al. 1994, David et al. 2004). Nineteen insect pest species have been reported from stored grains of Bangladesh (Alam 1971). The main insect pests

* Author for correspondence: <afm.aslam@gmail.com>.

(c) 2018 Zoological Society of Bangladesh DOI: https://doi.org/10.3329/bjz.v47i1.42016 
that attack stored grain cereals and pulses include the rice weevil - Sitophilus oryzae, pulse beetle - Callosobruchus chinensis and saw-toothed grain beetle Oryzaephilus surinamensis (Dhaliwal 2010). S. oryzae is one of the most important insect pests infesting stored rice, cereals, and seeds (Aslan et al. 2004). C. chinensis causes high losses during storage of a wide variety of legumes in the fields and seeds in storage. (Kang et al. 2013, Massango 2017). $O$. surinamensis is one of the serious pests of many kinds of food like dry fruits, spices, nuts, cereals and other cereal products (Padin et al. 2001). All these pests are worldwide in distribution (Srivastava and Subramanian 2016).

Insect identification relies on traditional taxonomy, which is primarily based on external morphology (Rebijith et al. 2012). However, taxonomic keys are often prepared for only certain life stages or genders; phenotypic variations in taxonomically important traits may also cause significant difficulties in species identification (Ball et al. 2006).

The taxonomic study revealed that, there exists a huge morphological variations within the species that lead huge dilemma to identify insects specially store pests (Ball et al. 2006, Singh et al. 2014). An important limitation in controlling these pests involves species identification (Sethusa et al. 2014). A novel methodology known as DNA barcoding has the potential to mitigate the challenges posed by identification of insect pests (Hanner 2009, Rugman-Jones 2009, Gariepy 2007, Quicke 2012, Sethusa et al. 2014). DNA barcoding is gaining broad application in integrated pest management (IPM) (Etzler et al. 2014) programs as the standard method for species identification by "matching unknown against the known" (Ball et al. 2006). DNA barcoding involves the PCR amplification and sequencing of a key genetic marker from a given specimen (Gariepy 2007). A short, standardized region of its genome, specifically the mitochondrial gene, cytochrome c oxidase subunit 1 (COI) is used in most of the cases (Hebert et al. 2003).This study was therefore aimed to investigate molecular characterization and identification of three important store grain pests of Bangladesh through establishing DNA barcode dataset. The main objectives behind this work are to associate morphological and molecular identification of the stored grain insect pests in order to find more strategies of managing these pests and for further research.

\section{MATERIAL AND METHODS}

DNA isolation: Three important stored grain pests Sitophilus oryzae, Callosobruchus chinensis and Oryzaephilus surinamensis were collected from different infested store grains. The genomic DNA was extracted from somatic tissue rich in mitochondria (e.g., leg or wing) using Wizard ${ }^{\circledR}$ Genomic DNA 
Purification Kit, USA, following the manufacturer's protocol. The remaining parts of insects and respective individuals were kept as voucher specimens. In short, separated tissue was ethanol sterilized and homogenized in $600 \mu \mathrm{l}$ nuclei lysis solution. After adding $3 \mu \mathrm{l}$ RNase and incubation in water bath for 15 minutes, $200 \mu \mathrm{l}$ protein precipitation solution was added. DNA containing supernatant was separated following $1400 \mathrm{rpm}$ centrifugation and added $600 \mu \mathrm{l}$ isopropanol into it. The solution was centrifuged at high speed to get DNA pellet. DNA was washed by $600 \mu \mathrm{l}$ of nuclease free $70 \%$ ethanol. The DNA was then air dried and rehydrated in $40 \mu \mathrm{l}$ DNA rehydration solution by incubating at $65^{\circ} \mathrm{C}$ for 1 hour. Processed DNA was stored at $4^{\circ} \mathrm{C}$ or $-20^{\circ} \mathrm{C}$.

DNA quantification and quality measurement: The quantity and purity of DNA was measured by using Nano drop ${ }^{\mathrm{TM}} 2000$ spectrophotometer (Thermo Fisher Scientific, USA). The ratio of the absorbence $A_{260} / A_{280}$ indicates the purity of PCR amplified DNA. For pure DNA, $\mathrm{A}_{260} / \mathrm{A}_{280}$ value is $\approx 1.8$.

Polymerase chain reaction (PCR): The extracts were subjected to PCR amplification of a $658 \mathrm{bp}$ region near the $5^{\prime}$ terminus of the $\mathrm{CO} 1$ gene following standard protocols. Primers used were forward primer: (LCO 1490 5'GGTCAACAAATCATAAAGATATTG G-3') and reverse primer: (HCO 2198 5'TAAACTTCAGGGTGACCAAAAAATCA-3'). PCR reactions were carried out in 96well plates with $20 \mu \mathrm{l}$ reaction volume containing Promega Gotaq ${ }^{\circledR}$ G2 Green Master Mix - $10 \mu \mathrm{l}$, forward and reverse primers - $1 \mu \mathrm{l}(10 \mathrm{pmol} / \mu \mathrm{l})$, template DNA, and nuclease free water (adjustable). Thermocycling consisted of an initial denaturation of $94^{\circ} \mathrm{C}$ for $3 \mathrm{~min}$, followed by 30 cycles of denaturation at $94^{\circ} \mathrm{C}$ for $30 \mathrm{sec}$, annealing at $49^{\circ} \mathrm{C}$ for $30 \mathrm{sec}$, extension at $72^{\circ} \mathrm{C}$ for $1 \mathrm{~min}$, final extension: $72^{\circ} \mathrm{C}$ for $10 \mathrm{~min}$ and hold: $4^{\circ} \mathrm{C}$. PCR was performed using a Veriti ${ }^{\circledR}$ Thermal Cycler from Thermo Fisher Scientific Thermal Cycler.

Gel electrophoresis: The amplified product was analysed on a 1.5\% agarose gel electrophoresis. The DNA was then visualized under gel documentation system - BioDoc Analyzer of Biometra.

Sequencing: The PCR products were purified using Promega Wizard ${ }^{\circledR}$ SV Gel and PCR clean up system manufactured by Promega Corporation, USA following manufacturer's protocol. The quantity and purity of PCR purified products was checked by spectrophotometer. DNA sequencing was performed to determine the nucleotide sequence in cytochrome oxidase I region. BigDye ${ }^{\circledR}$ Terminator v3.1 cycle sequencing kit was used in this process. Each species was bi-directionally sequenced to get sequence of both (5' and 3') the DNA strands.

Submission of gene to GenBank: Sequenced data were checked for quality by BioEdit v.7.0.5 software. Homology, insertions - deletions, stop codons, and framshifts was checked using NCBI BLAST. BankIt, a WWW-based submission 
tool with wizards to guide the submission process was used. The GenBank database was intended for new sequence data that was determined and annotated by the submitter. All sequences were uploaded to GenBank.

Data analysis: The chromatograms were converted to FASTA format using FinchTV chromatogram viewer software. The DNA sequences in ABI file were manually edited using BioEdit v.7.0.5. Results of sequence editing were analyzed using BLAST (Basic local alignment search tool) NCBI to indicate the homology from closest species. Phylogenetic tree was constructed using maximum likelihood method, calculation using Bootstrap with 1000 times of repetition in Molecular evolutionary genetic analysis (MEGA) software program v.X (Kumar et al. 2018).

\section{RESULTS AND DISCUSSION}

To confirm that the desired portion of COI gene has been amplified, gel electrophoresis was conducted. Thermo Fisher GeneRular $100 \mathrm{bp}$ was used as ladder. The gel documentation image obtained by BioDoc Analyzer shows that all the samples selected for gel electrophoresis gave bands between 600 and $700 \mathrm{bp}$ of DNA ladder (Fig. 1). It reveals that desired COI gene of mtDNA were properly polymerased. The visualized PCR product contained no double bands on agarose gel, thus indicating that sequences obtained were targeted mitochondrial DNA and not nuclear or mitochondrial mistargets.

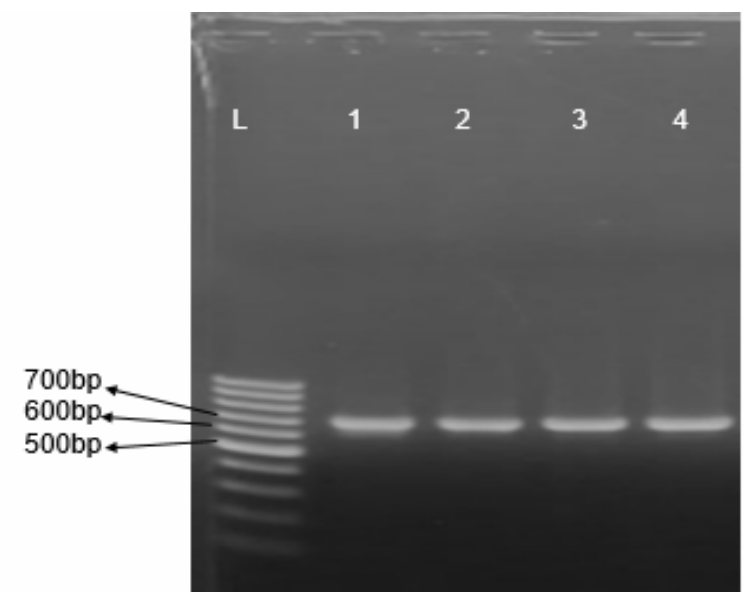

Fig. 1. Agarose gel electrophoresis of mitochondrial Cytochrome oxidase subunit I (COI) from S. oryzae (1,2), C. chinensis (3) and O. surinamensis (4). L = $100 \mathrm{bp}$ Ladder.

Sequence result and BLAST analysis: A total of 3 insect species were sequenced. All 3 species could be differentiated by $\mathrm{CO} 1$ barcoding. Most of the amplified sequences were up to $658 \mathrm{bp}$ in length. National Center for 
Biotechnology Information (NCBI) basic local alignment search tool (BLAST) was used to check homology between the retrieved sequences and GenBank library or database of sequences. This helps to identify sequence similarity across genomes.

BLAST analysis revealed that the observed sequence no.1 shows 99\% homology with the sequences in GenBank submitted from India, France, Japan and China (Table 1). It indicates that the observed sample is Callosobruchus chinensis.

Table 1. BLAST analysis of sequence no. 1 for C. chinensis

\begin{tabular}{lccccc}
\hline $\begin{array}{l}\text { Species } \\
\text { name }\end{array}$ & $\begin{array}{c}\text { Total } \\
\text { score }\end{array}$ & $\begin{array}{c}\text { Query cover } \\
(\%)\end{array}$ & $\begin{array}{c}\text { Identity } \\
(\%)\end{array}$ & E value & $\begin{array}{l}\text { GenBank } \\
\text { Acc. no. }\end{array}$ \\
\hline C. chinensis & 1190 & 94 & 99 & 0.0 & JQ906102.1 \\
$"$ & 824 & 67 & 99 & 0.0 & AY625416.1 \\
$"$ & 798 & 64 & 99 & 0.0 & DQ459043.1 \\
$"$ & 1221 & 97 & 99 & 0.0 & KY856744.1 \\
\hline
\end{tabular}

In Table 2, BLAST analysis showed that the observed sequence no. 2 has 99\% homology with the sequences of GenBank from India, USA and China. It reveals that the observed sample is Sitophilus oryzae.

Table 2. BLAST analysis of sequence no. 2 for S. oryzae

\begin{tabular}{lccccl}
\hline $\begin{array}{l}\text { Species } \\
\text { name }\end{array}$ & $\begin{array}{c}\text { Total } \\
\text { score }\end{array}$ & $\begin{array}{c}\text { Query cover } \\
(\%)\end{array}$ & $\begin{array}{c}\text { Identity } \\
(\%)\end{array}$ & E value & $\begin{array}{l}\text { GenBank } \\
\text { Acc. no. }\end{array}$ \\
\hline S. oryzae & 1202 & 98 & 99 & 0.0 & KY912942.1 \\
$"$ " & 1191 & 98 & 99 & 0.0 & AY131099.1 \\
$"$ " & 1193 & 97 & 99 & 0.0 & KY912940. \\
& 1187 & 97 & 99 & 0.0 & KY912934.1 \\
\hline
\end{tabular}

Another BLAST analysis disclosed that the observed sequence of sequence no. 3 showed 100\% homology with accession no. KU494196.1 and 99\% homology with accession no. KU494194.1; MH910059.1, but 98\% with MG458964.1 of the database sequences from France, India, USA and China (Table 3). It proved that the observed species is Oryzaephilus surinamensis.

Table 3. BLAST analysis of sequence no. 3 for 0 . surinamensis

\begin{tabular}{lccccl}
\hline $\begin{array}{l}\text { Species } \\
\text { name }\end{array}$ & $\begin{array}{c}\text { Total } \\
\text { score }\end{array}$ & $\begin{array}{c}\text { Query cover } \\
(\%)\end{array}$ & $\begin{array}{c}\text { Identity } \\
(\%)\end{array}$ & E value & $\begin{array}{l}\text { Genbank } \\
\text { Acc. no. }\end{array}$ \\
\hline O. surinamensis & 1150 & 99 & 100 & 0.0 & KU494196.1 \\
$" ~$ & 1141 & 97 & 99 & 0.0 & KU494194.1 \\
$" ~$ & 1122 & 95 & 99 & 0.0 & MH910059.1 \\
$"$ & 1128 & 94 & 98 & 0.0 & MG458964.1 \\
\hline
\end{tabular}


All mitochondrial CO1 sequences were submitted to the NCBI-GenBank under accession numbers provided in Table 4.

Table 4. GenBank accession no. of three stored grain pests

\begin{tabular}{ll}
\hline Species name & GenBank Accession no. \\
\hline Sitophilus oryzae & MG967331.1; MG967332.1 \\
Callosobruchus chinensis & MG967333.1 \\
Oryzaephilus surinamensis & MK041216.1 \\
\hline
\end{tabular}

Nucleotide composition of COI gene sequences: Retrieved sequences were subjected for analysis of nucleotide composition (Table 5). Codon positions included were $1 \mathrm{st}+2 \mathrm{nd}+3 \mathrm{rd}+$ non-coding. All positions containing gaps and missing data were eliminated from the dataset. The A, T, G, C, AT, and GC content of all sequences was obtained using a computer program (MEGA v.10.0). The maximum average value of thymine $(\mathrm{T})$ is $33.3 \%$ and the minimum value of guanine $(\mathrm{G})$ is $15.3 \%$. The highest percentage of thiamine $(\mathrm{T}, 34.4)$ and adenine (A, 33.5) was found in S. oryzae 2 and $O$. surinamensis, respectively. On the contrary, the lowest percentage of Guanine $(\mathrm{G}, 13.8)$ and cytosine $(\mathrm{C}, 18.8)$ was found in $O$. surinamensis, and $C$. chinensis, respectively. The maximum percentage of adenine and thiamine $(\mathrm{A}+\mathrm{T}, 65.4)$ was found in $S$. oryzae 2 and the minimum percentage of guanine and cytosine $(G+C, 34.5)$ was also found in S. oryzae 2. As expected, AT content (64.8\%) was found significantly higher than the GC content of $35.2 \%$.

Table 5. Nucleotide composition of $\mathrm{CO1}$ gene sequence of selected store pest species

\begin{tabular}{llllllll}
\hline Sp. name with ID & $\mathrm{T}$ & $\mathrm{C}$ & $\mathrm{A}$ & $\mathrm{G}$ & Total & $\mathrm{A}+\mathrm{T}$ & $\mathrm{G}+\mathrm{C}$ \\
\hline C. chinensis & 34.3 & 18.8 & 30.5 & 16.4 & 688.0 & 64.8 & 35.2 \\
S. oryzae 1 & 34.1 & 19.4 & 31.0 & 15.5 & 684.0 & 65.1 & 34.9 \\
S. oryzae 2 & 34.4 & 19.2 & 31.0 & 15.3 & 686.0 & 65.4 & 34.5 \\
O. surinamensis & 30.3 & 22.4 & 33.5 & 13.8 & 617.0 & 63.8 & 36.2 \\
Average & 33.3 & 19.9 & 31.5 & 15.3 & 668.8 & 64.8 & 35.2 \\
\hline
\end{tabular}

Genetic distance analysis: The genetic distance among four sequences of three store pests ranged from $0.00293-0.32807$. Standard errors estimates are shown above the diagonal and were obtained by a bootstrap procedure (1000 replicates). Analysis was conducted using the Kimura 2-Parameter model. Genetic distance denotes the mutation among individuals. The lowest genetic distance (0. 0.00293) was found in S. oryzae 2 and the highest genetic distance (0. 32807) was found in O. surinamensis (Table 6). 
Table 6. Genetic distance among 3 store pest species using Kimura 2 parameter (K2P)

\begin{tabular}{lllll}
\hline Species & 1 & 2 & 3 & 4 \\
\hline S. oryzae & - & & & \\
S. oryzae 2 & 0.00293 & - & & \\
C. chinensis & 0.30409 & 0.30714 & - & - \\
O. surinamensis & 0.29220 & 0.29220 & 0.32807 & - \\
\hline
\end{tabular}

Multiple sequence alignment: Sequences were aligned using the MEGA v.10.0. Residue and pairwise distances were estimated using the Clustal $\mathrm{W}$ tool with default settings of gap opening penalty 15, and a gap-extension 6.6 in pairwise alignment and 0.05 in multiple alignments. Multiple sequence alignment of four COI gene nucleotide sequences of three stored grain insect pests are given in Fig. 2. Non-conserved regions were presented by letter and identical or conserved regions were indicated by dot.

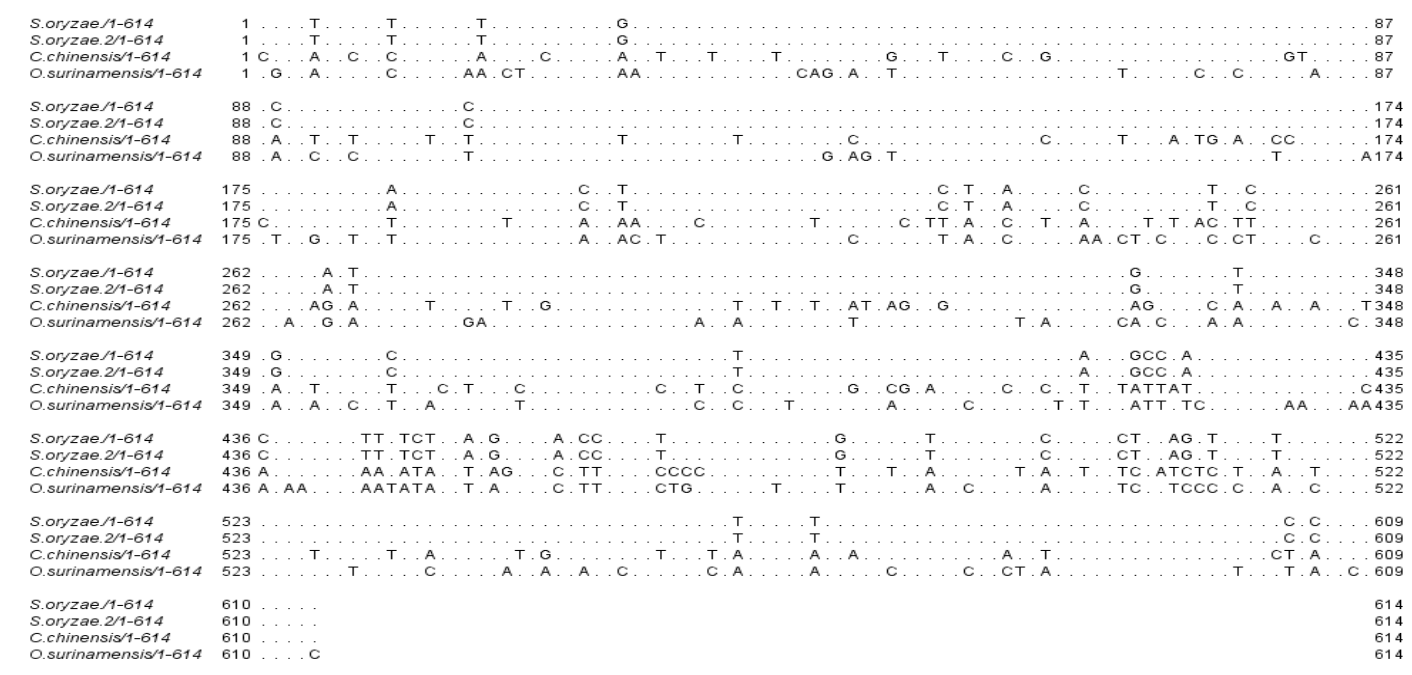

Fig. 2. Multiple sequence alignment based on COI gene sequences of stored grain insect pests. Letter denotes the conserved region and dot means non conserved portion among these four nucleotide sequences.

Haplotype: Haplotype analysis of mitochondrial COI gene of three stored grain insect pests showed high genetic diversity among them (Fig. 3). They were separated from their common ancestor by 73,64 and 80 mutational steps. $C$. chinensis showed 80 mutated sites which is the highest amount followed by $O$. surinamensis and S. oryzae which showed 73 and 64 mutated sites, respectively.

Phylogenetic analysis: Maximum likelihood (ML) tree was analyzed to find the phylogenetic relationship among the samples of store pests using MEGA v.10.0 software. According to maximum likelihood with 1000x bootstrap 
repetition, a phylogeny was constructed (Fig. 4) by the MEGA v.10.0 software using analyzed four sequences (marked BD*) of three species. A total of 20 sequences from different parts of the world available in the NCBI GenBank were used for a proper comparison. The tree consisted of three distinct major clades that represent three families of the order Coleoptera. Three species of S. oryzae, $O$. surinamensis and C. chinensis represent Curculionidae, Cucujidae and Bruchidae family, respectively.

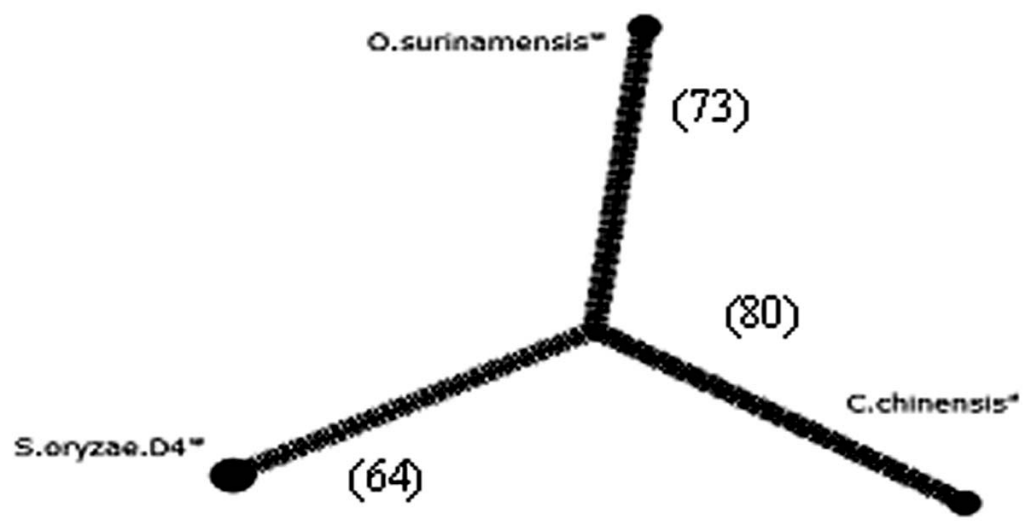

Fig. 3. Mitochondrial COI gene haplotype analysis of stored grain pests species constructed by Popart 1.7 based on TCS network. Black circles represent the haplotype and small black circle represent the common ancestor. Mutational steps are presented by hatch marks and numbers

S. oryzae species from different countries are originated from the same clade showing $100 \%$ genetic similarities which indicates their same origin, while $O$. surinamensis and C. chinensis are originated from different clades. This evolutionary phylogeny denotes that these species are originated from the same order but separated in taxa family. The bar at the bottom provides a scale for the genetic change. In this case, the line segment with the number '0.05' shows the length of branch that signifies an amount genetic change of 0.050 .

The present study successfully identified three stored grain insect pest species. The sequences obtained in the present study were stored in GenBank databases. BLAST analysis revealed 99 to $100 \%$ similarity with the existing databases. Phylogenetic analysis proves that S. oryzae, C. chinenesis and $O$. surinamensis were originated from different clades that means they belong to different families of the order Coleoptera. A $+\mathrm{T}$ content was greater than the $\mathrm{G}+\mathrm{C}$ content which is usual in mitochondrial genes. Various information acquired from this study could be used for further researches including effective pest management. 


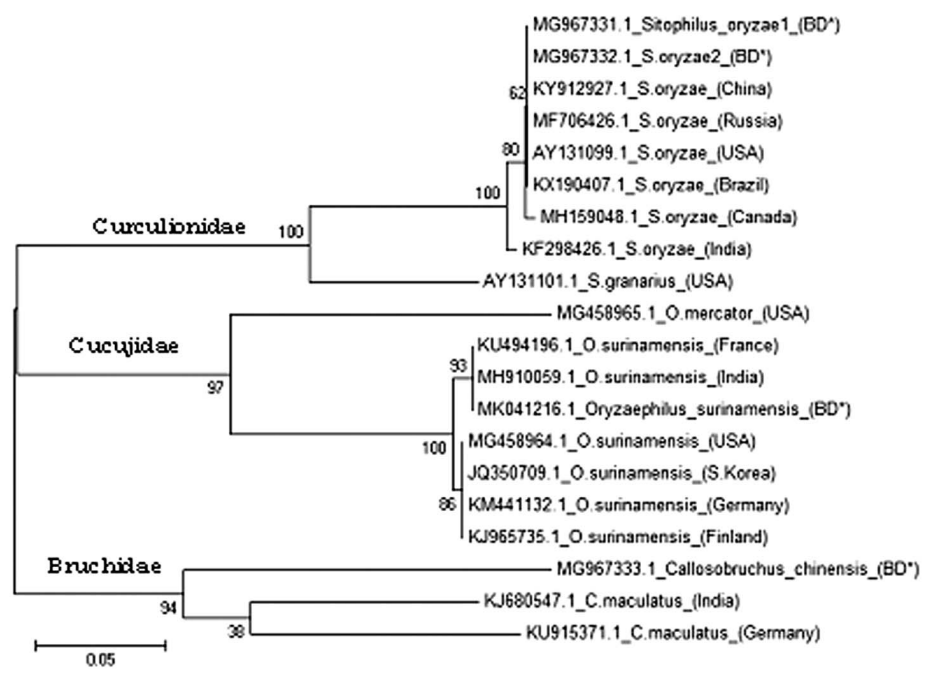

Fig. 4. Molecular phylogenetic analysis by maximum likelihood method. The evolutionary history was inferred using the maximum likelihood method based on the Tamura-Nei model. The tree is drawn to scale, with branch lengths measured in the number of substitutions per site. The percentage of trees in which the associated taxa clustered together is shown above the branches.

Over the last decade the field of DNA barcoding has emerged as a molecular method for species identification. The goal of scientists who perform DNA barcoding is to create a library of every organism on earth (Stoeckle et al. 2004, Kerr et al. 2007). Although the major insect pests in food are widespread worldwide, only a few studies have been conducted on the DNA barcodes for these species (Seo et al. 2013). Therefore, this study is the first to attempt construction of a DNA reference dataset using the mitochondrial COI gene from store food-associated insect species. This dataset can be effectively used to identify store food-associated insect pests that are currently important in commercial food markets. DNA barcoding can help in identifying pests in any stage of life making easier to control them saving farmers from cost of billion dollars from pest damage (Kaur 2015, Sarvananda 2018).

Acknowledgement: This work was supported in part by grant of Higher Education Quality Enhancement Project - CP No. 3424, a project of University Grants Commission of Bangladesh and Ministry of Education, Bangladesh.

\section{LITERATURE CITED}

ALAM, M.Z. 1971. Pests of stored grains and other products and their control. Agric. Inf. Service, 3 R.K. Mission Road, Dacca-3. 61 pp.

ASLAN, I., OZBEK, H., ONDER, C. and SAHIN, F. 2004. Toxicity of essential oil vapours to two greenhouse pests, Tetranychus urticae Koch and Bemisia tabaci Genn. Ind. Crops. Prod. 19: 167-173. 
BALL, S.L. and ARMSTRONG, K.F. 2006. DNA barcodes for insect pest identification. Canadian J. Forest Res. 36(2): 337-350.

BHUIYAH, M.I.M., ISLAM, N., BEGUM, A. and KARIM, M.A. 1990. Biology of the rice weevil, Sitophilus oryzae (L.). Bangladesh J. Zool. 18(1): 67-73.

DAVID, K.W. and REEVEES, P.A. 2004. Pest management for grain storage and fumigation. Montana State University, Department of Entomology, 333 Leon Johnson Hall, Boseman, MT. $213 \mathrm{pp}$.

DHALIWAL, G.S., JINDAL, V. and DHAWAN, A.K. 2010. Insect pest problems and crop losses: changing trends. Indian J. Ecol. 37(1): 1-7.

ETZLER, F. E., WANNER, K.W., MORALES R. A. and IVIE, M. A. 2014. Barcoding to improve the species-level management of wireworms (Coleoptera: Elateridae). J. Econ. Entomol. 107(4): 14761485.

GARIEPY, T., KUHLMANN, U., GILLOTT, C. and ERLANDSON, M. 2008. A large-scale comparison of conventional and molecular methods for the evaluation of host parasitoid associations in nontarget risk-assessment studies. J. Appl. Ecol. 45(2): 708-715.

HANNER, R.H., LIMA, J. and FLOYD, R. 2009. DNA barcoding and its relevance to pests, plants and biological control. Acta Hortic. 823: 41-48.

HEBERT, P.D.N., CYWINSKA, A., BALL, S.L. and JEREEMY, R. deWAARD. 2003. Biological identifications through DNA barcodes. Proc. R. Soc. Lond. B. Biol. Sci. 270: 313-321.

HILL, D.S. 1990. Pests of stored products and their control. Belhaven press, Boca Raton, FL, p. 274.

KANG, J.K., PITTENDRIGH, B.R. and ONSTAD, D.W. 2013. Insect resistance management for stored product pests: a case study of cowpea weevil (Coleoptera: Bruchidae). J. Econ. Entomol. 106(6): 2473-90.

KAUR, S. 2015. DNA barcoding and its applications. Int. J. of Eng. Res. and Gen. Sci. 3(2): 602-604.

KERR, K.C.R., STOECKLE, M.Y., DOVE, C.J., WEIGT, L.A., FRANCES, C.M. and HEBERT, P.D.N. 2007. Comprehensive DNA barcode coverage of North American birds. Mol. Ecol. Notes. 7: 535543.

KIMURA, M. 1980. A simple method for estimating evolutionary rates of base substitutions through comparative studies of nucleotide-sequences. J. Mol. Evol. 16: 111-120.

KUMAR, S., STECHER, G., LI, M., KNYAZ, C. and TAMURA, K. 2018. MEGAX: Molecular evolutionary genetics analysis across computing platforms. Mol. Biol. Evol. 35(6): 1547-1549.

MASSANGO, H., FARONI, L., HADDI, K., HELENO, F., JUMBO, L.V. and OLIVEIRA, E. 2017. Toxicity and metabolic mechanisms underlying the insecticidal activity of parsley essential oil on bean weevil, Callosobruchus maculatus. J. Pest Sci. 90(2): 723-33.

OERKE, E.C., DEHNE, H.W., SCHONBECK, F. and WEBER, A. 1994. Crop production and crop protection-estimated losses in major food and cash crops. Amsterdam: Elsevier Science. xxii + $808 \mathrm{pp}$.

PADIN, S., DAL, B. G. and FABRIZIO, M. 2001. Grain loss caused by Tribolium castaneum, Sitophilus oryzae and Acanthoscelides obtectus in stored durum wheat and bean treated with Beauveria bassiana. J. Stored Prod. 38(1): 69-74.

GUICKE, D.L., ALEX SMITH, M., JANZEN, D.H., HALlWACHS, W., FERNANDEZ-TRIANA, J., LAURENNE, N.M., ZALDIVAR-RIVERON, A., SHAW, M.R., BROAD, G.R. and KLOPFSTEIN, S. 2012. Utility of the DNA barcoding gene fragment for parasitic wasp phylogeny (Hymenoptera: Ichneumonoidea): Data release and new measure of taxonomic congruence. Mol. Ecol. Resour. 12: $676-685$. 
REBIJITH, K. B., ASOKAN, R., KRISHNA, V. N. K., KRISHNA, K. and RAMAMURTHY, V. V. 2012. DNA Barcoding and development of species-specific markers for the identification of tea mosquito bugs (Miridae: Heteroptera) in India. Fla Entomol. 95(3): 674-682.

RUGMAN-JONES, P. F., ROBERT, W., TOM, van NOORT. and RICHARD, S. 2009. Molecular differentiation of the Psyttaliaconcolor (Szépligeti) species complex (Hymenoptera: Braconidae) associated with olive fly, Bactrocera oleae (Rossi) (Diptera: Tephritidae), in Africa. J. Biol. Control. 49(1): 17-26.

SARVANANDA, L. 2018. Short introduction of DNA barcoding. Int. J. Res. 5(4): 673-685.

SEO, Y.C., KYONG, S. and BAE, Y. J. 2013. DNA barcode library and its efficacy for identifying foodassociated insect pests in Korea. Entomol. res. 43: 253-261.

SETHUSA, M.T., MILlAR, I.M., YESSOUfOU, K., JACOBS, A., VAN DER BANK, M. and VAN DER BANK, H. 2014. DNA barcode efficacy for the identification of economically important scale insects (Hemiptera: Coccoidea) in South Africa. African J. Zool. 22(1): 257-267.

SINGH, B.B. and SINGH, R. 2014. Major rice insect pests in north eastern UP. Int. J. Life Sc.Bt \& Pharm. 3(1): 124-143.

SRIVASTAVA, C. and SUBRAMANIAN, S. 2016. Storage insect pests and their damage symptoms: an overview. Indian J. Entomol. 78: 53-58.

STOECKLE, M., WAGGONER, P.E. and AUSUBEL, J.S. 2004. Barcoding life: Ten reasons. consortium for the barcode of life, v3.0. Retrieved from: http://www.barcodeoflife.org/ content/barcoding-life-ten-reasons-pamphlet.

(Manuscript received on 30 January, 2019; revised on 23 April, 2019) 